\title{
LONG-TERM MONITORING OF GLACIER CHANGE AT GÖSSNITZKEES (AUSTRIA) USING TERRESTRIAL PHOTOGRAMMETRY
}

\author{
V. Kaufmann ${ }^{\text {a, } *}$, G. Seier ${ }^{\text {b }}$ \\ ${ }^{a}$ Institute of Geodesy, Graz University of Technology, Steyrergasse 30, 8010 Graz, Austria - \\ viktor.kaufmann@tugraz.at \\ ${ }^{\mathrm{b}}$ Department of Geography and Regional Science, University of Graz, Heinrichstraße 36, 8010 Graz, Austria - \\ gernot.seier@uni-graz.at
}

\section{WG VIII/6}

KEY WORDS: Terrestrial photogrammetry, Monitoring, Glacier change, Consumer camera, SfM, Automation, Gössnitzkees

\begin{abstract}
:
Gössnitzkees is a small heavily debris-covered cirque glacier (49.8 ha) located in the Schober Mountains, Hohe Tauern Range, Austrian Alps. Glacier nourishment is mainly due to avalanches descending from its surrounding headwalls. Gössnitzkees is the largest glacier in the Schober Mountains and is highly representative of the other 25 glaciers of this mountain group. All glaciers of this mountain group have receded continuously since 1850 . Ongoing atmospheric warming sustains excessive glacier melt. In 1988 a long-term monitoring program was started at Gössnitzkees using terrestrial photogrammetry in order to document and quantify glacier change. The surveys have been repeated from time to time using different types of cameras. Recent surveys date from 2009 , 2012, and 2015. The aim of this paper is twofold: firstly, to investigate whether or not the rather complex photogrammetric evaluation process using a conventional photogrammetric workstation (mostly with a limited degree of automation for terrestrial applications) can be replaced by modern fully automated Structure-from-Motion (SfM) based approaches, and secondly, to document and quantify the glacier change at Gössnitzkees based on available information augmented by results obtained from the most recent surveys mentioned. Over the last 27 years (1988-2015) the terminus of Gössnitzkees has receded by $179 \mathrm{~m}$ and the glacier ice has melted at a mean annual rate of about $1.5 \mathrm{~m} /$ year. The Schober Mountains are in the process of deglaciation and the glaciers will likely disappear within the next two decades. Based on our practical investigations we found out that SfM-based software is in general capable of handling terrestrial photographs in a fully automatic mode supporting challenging glacier studies.
\end{abstract}

\section{INTRODUCTION}

Climate change has a significant impact on the alpine environment. Atmospheric warming affects, e.g., the alpine cryosphere: glaciers are melting and permafrost is degrading (Winkler et al., 2010; Deline et al., 2015). According to Wakonigg (2007: 103), the mean annual temperature in Austria has increased by $1.8^{\circ} \mathrm{C}$ during the observation period 1885 2003.

The mass balance of glaciers can be determined either by the glaciological or the geodetic method. The pros and cons of both observation methods are discussed, e.g., in Fischer (2011), Huss (2013), and Zemp et al. (2013). The geodetic method may be either image-based or LIDAR-based. Glacier area and glacier flow velocity are other important glaciological observables. Different measurement techniques exist (Kääb, 2005; Paul et al., 2015).

Terrestrial photogrammetry played an important role in the early days of mountain cartography (Kriz, 2015) and was thus often used in glacier change studies (Rinner \& Burkhardt, 1972; Mayer, 2010). As already communicated in Kaufmann (2008), the authors believe that this ground-based mapping technique could still serve as a cheap and viable technique for monitoring alpine glaciers. Due to its inherent technical limitations, however, terrestrial photogrammetric surveys should be restricted to small areas, i.e., glacier tongues, profiles, and other areas of interest of small spatial extent (Kajuutti et al., 2010; Maas et al., 2012; Sanz-Ablanedo et al., 2012; Kaufmann et al., 2013).

We argue that glacier mapping based on terrestrial photogrammetry is beneficial for two reasons: (1) data acquisition using digital consumer-grade cameras is cheap and highly flexible and (2) data evaluation for glaciological studies can be easy and fast if done appropriately. Both facts are in support of democratization of photogrammetry (cp. with Rüdenauer, 1996). These findings are also true for other applications where mass movements are present, such as monitoring of rock glaciers, rock slopes and landslides (see, e.g., Kaufmann, 2012).

The remainder of the paper is organized as follows: Section 2 describes the geography of Gössnitzkees. Section 3 outlines previous research work carried out on the glacier. Data acquisition of the glacial stages 2009, 2012, and 2015 is summarized in Section 4. Section 5 describes the automation of the photogrammetric evaluation process using commercial software solutions, such as, ImageStation of Intergraph, PhotoModeler Scanner, Agisoft PhotoScan, and Pix4Dmapper Pro. Section 6 reports the results obtained focusing on technical intercomparison of methods and relevant glaciological

\footnotetext{
* Corresponding author
} 
information. The paper ends with a short discussion followed by an outlook.

\section{GEOGRAPHICAL SETTING OF GÖSSNITZKEES}

Gössnitzkees $\left(46^{\circ} 56^{\prime} 00^{\prime \prime} \mathrm{N}, 12^{\circ} 45^{\prime} 45^{\prime \prime}\right.$ E) is a small cirque glacier located at the valley head of Gössnitz Valley, Schober Mountains, Austria (Figures $1 \& 2$ ). It can be reached from the village of Heiligenblut following a mountain trail to Elberfelderhütte (Alpine hut, $2344 \mathrm{~m}$ ), from where it is a 45 minute walk to the lower end of Gössnitzkees $(2513 \mathrm{~m})$. The Schober Mountains belong to the Hohe Tauern Range, Eastern Alps. The study area itself is located in the core zone of the Hohe Tauern National Park.

Gössnitzkees has a present-day size of approx. 49.8 ha according to the Austrian Glacier Inventory (Fischer et al., $2015 \mathrm{a}, \mathrm{b})$ and it is the largest glacier in the Schober Mountains. The cirque of Gössnitzkees is confined on three sides by mountain crests higher than $3000 \mathrm{~m}$ (Figure 2). Due to this topographic situation the potential accumulation area of Gössnitzkees is limited, and thus the glacier is mainly nourished by avalanches coming down from the surrounding steep couloirs. As a result, the glacier is largely covered by debris (Figure 4). The local climate of the area with relatively low precipitation is a result of its specific inner-alpine location (Lieb, 2000). In 1850 the size of Gössnitzkees was approx. 137.8 ha (Fischer et al., 2015b; areal extent/lateral moraines of 1850 see Figure 2). The glacier has thus shrunk by $63.9 \%$ since 1850. Each summer a small proglacial lake (approx. $0.76 \mathrm{ha}$ ) develops, marking the lower end of the glacier (Figures $2 \& 4$ ).

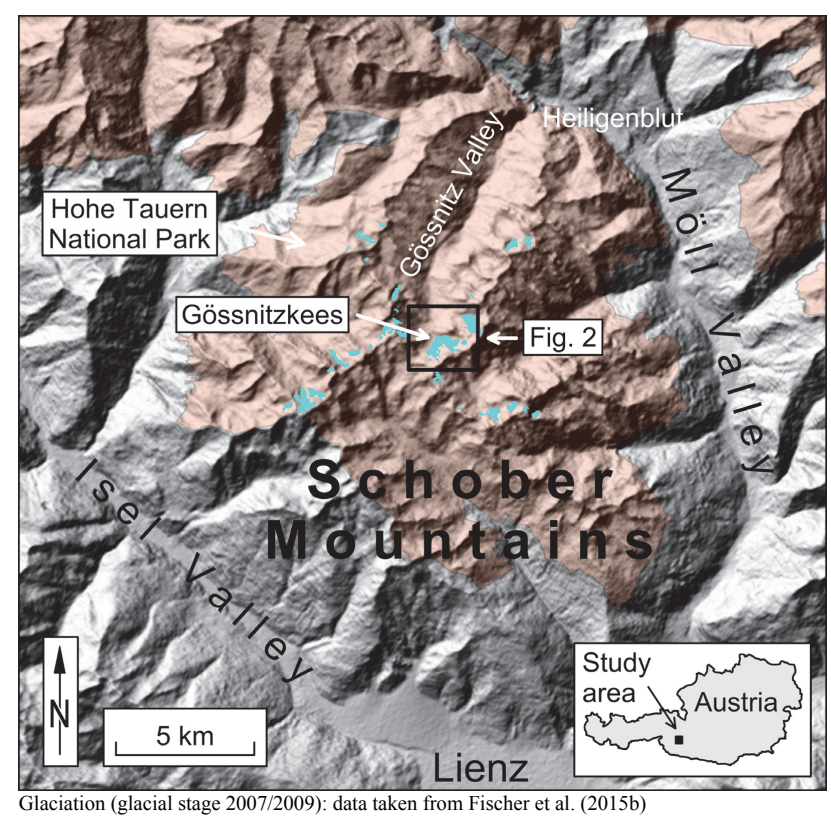

Data source of digital elevation model: Land Tirol - data.tirol.gv.at

Figure 1. Location map

\section{PREVIOUS WORK}

The spatio-temporal change of Gössnitzkees has already been studied in various projects applying different mapping/observation techniques at different time scales and accuracy levels. For reasons of comparison see Fischer et al. (2014).

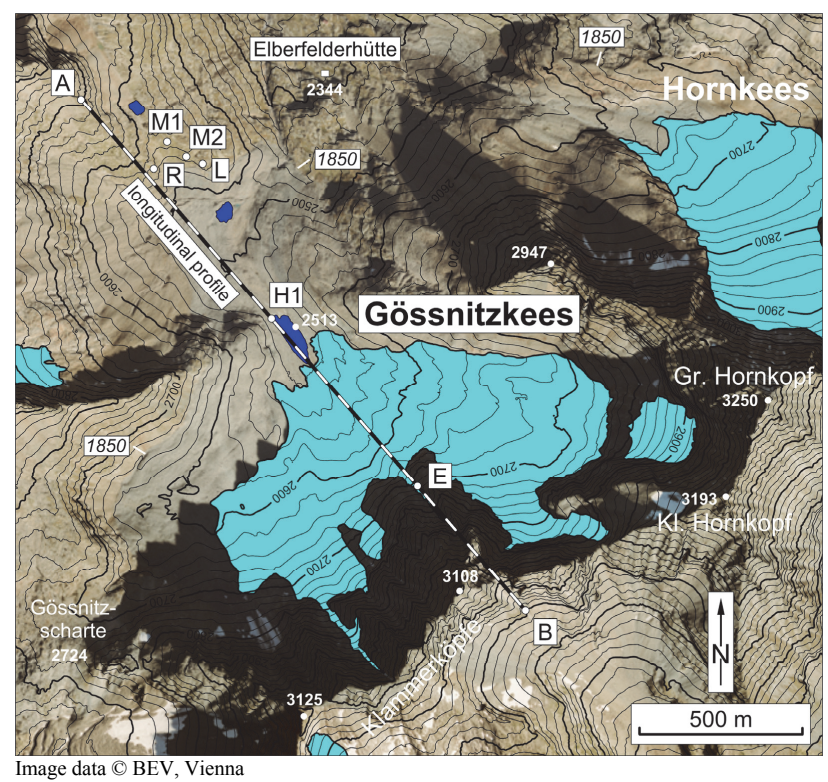

Figure 2. Local map (situation of 2006)

\subsection{Measurement of glacier length change}

In 1982 annual measurements of glacier length change were started at Gössnitzkees within the framework of the glacier survey of the Austrian Alpine Club (Lieb, 2000). Simple distance measurements document the horizontal length change of the glacier. The results obtained are published on an annual basis (e.g., Fischer, 2015).

\subsection{Austrian glacier inventory}

All glaciers in Austria were mapped by means of aerial photogrammetry and/or airborne laser scanning (ALS) at three different epochs, i.e., 1969, 1989, and 2006 (Patzelt, 1980; Lambrecht \& Kuhn, 2007; Abermann et al., 2010; Fischer et al., 2015a). Relevant glaciological data, such as areal extent and digital elevation models, are digitally available for each glacier (Fischer et al., 2015b). Statistical parameters, such as change in area and volume, can be retrieved. The glacial stage of 1850 (Little Ice Age, recent maximum glaciation) was also mapped using orthophotos and ALS data (Fischer et al., 2015a).

\subsection{Glacier history 1850-2006}

The course of deglaciation of Gössnitzkees was mapped with higher temporal resolution using field evidence, old maps, and preferably multi-year aerial photographs (Kaufmann \& Lieb, 2002; Kaufmann \& Plösch, 2000; Kaufmann \& Ladstädter, 2008a).

\subsection{Geodetic measurements 1996-2015}

Annual geodetic measurements (tacheometry, RTK-GNSS) have been carried out every year in August since 1996. The front end and also the central part (longitudinal profile, see Figures $2 \& 4$ ) of Gössnitzkees are surveyed on a regular basis. Results can be retrieved from Kaufmann (2016a). 


\subsection{Terrestrial laser scanning}

Experimental results of terrestrial laser scanning (TLS) of Gössnitzkees were published, e.g., in Kellerer-Pirklbauer et al. (2005). TLS was found highly appropriate for this specific glacier mapping task.

\subsection{Terrestrial photogrammetric surveys 1988-2009}

Several terrestrial photogrammetric surveys have been carried out using different analog and/or digital cameras (Kaufmann \& Ladstädter 2004, 2008b; Kaufmann, 2010). The last survey of 2009 is also the basis (= first epoch) of this paper's time-series evaluation. Terrestrial photographs were always taken from the same positions L, M1, M2, and R, located at the counter slope of Gössnitzkees (Figures 2, $3 \& 4$ ) and marked with cairns. For indirect georeferencing of these image data $3 \mathrm{D}$ coordinates of 54 natural ground control points (GCPs) were determined in a combined geodetic and photogrammetric approach (white dots in Figure 4).

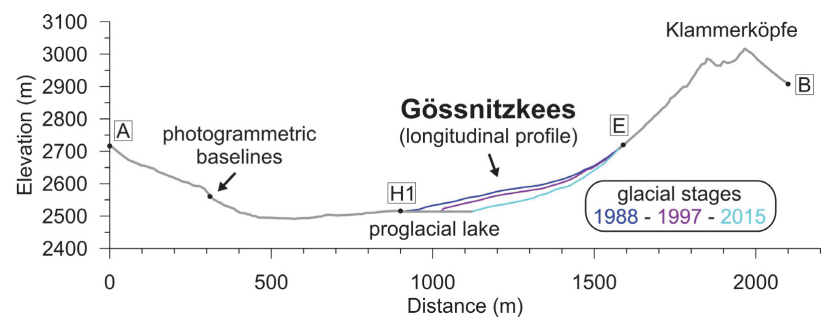

Figure 3. Cross section (profile A-B) showing the glacial stages 1988-1997-2015.

\section{DATA ACQUISITION}

Terrestrial photogrammetric surveys were carried out on 22 Aug. 2009, 17 Aug. 2012, and 21 Aug. 2015 always using the same equipment, i.e., a consumer-grade digital SLR camera Nikon D300 (DX format, 12 megapixels) equipped with a $50 \mathrm{~mm} \mathrm{f} / 1.8$ NIKKOR lens. The focus ring was set to infinity (end stop). Photographs of Gössnitzkees were always taken from the same four positions L, M1, M2, and R (Figure 2). The viewing direction was chosen in such a way that the area of interest was approx. in the center of the photo and all GCPs were visible in the photo frame (cp. Figure 4). A light-weight photographic tripod with a 3-way pan-tilt head was used to adjust viewing direction and to prevent camera movement. A Hama Double Bubble Level slipped on the camera shoe mount helped to level the long side of the camera. Original image data was stored in raw/NEF format and later on converted to 8-bit TIF format using Nikon Capture NX 2. In 2015 the original image data was mistakenly stored as JPG files only.

The annual geodetic surveys of Gössnitzkees were carried out either shortly before or after the photographs were taken, which made it then possible to independently check the accuracy of the terrestrial photogrammetric results. The geodetic surveys comprise the measurement of the glacier boundary (lower end of the glacier), the longitudinal profile as shown in Figure 5, ten marked points on the glacier, and the areal extent of the proglacial lake.

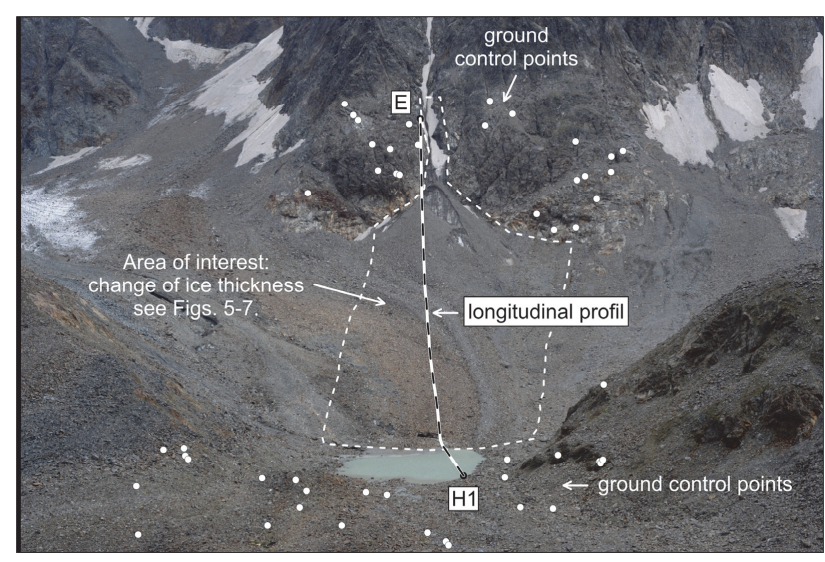

Figure 4. Nikon D300 digital image (21 Aug. 2015, taken at position R) showing the central part of Gössnitzkees. Ground control points (GCPs), the longitudinal profile, and the area of interest are indicated.

\section{METHODS}

In our study we intended to use commercial software only.

\subsection{Digital photogrammetric workstation (ImageStation)}

This approach is based on the traditional photogrammetric mapping scheme using stereopairs only. It is assumed that the interior orientation (IO) of the camera used is known. In the present study we used an earlier camera calibration of 2008 (Kaufmann, 2010). In a geometric pre-processing step the original image data is idealized/normalized to obtain a perfect central perspective geometry (Kaufmann \& Ladstädter, 2008b). Practical work was carried out on an Intergraph digital photogrammetric workstation (DPW) (ImageStation, 2016). We worked with software version 13.0.

5.1.1 Intergraph (ISSD, ISFC): Stereomodel setup (image pair M2-R) was accomplished interactively. In the majority of cases automatic point transfer failed due to strong perspective distortions. Many trials were needed to circumvent inversion of the stereobase. This annoying effect was caused by the automatic computation of baseline orientation based on the actual overlap of the two images. GCPs were measured stereoscopically. A final bundle adjustment solved the pose estimation. Feature collection (glacier boundaries, structural lines, grid points with a spacing of $5 \mathrm{~m}$, and additional points) was done interactively. Using this data, a digital elevation model (DEM) with a grid spacing of $2.5 \mathrm{~m}$ was computed for each epoch.

A modern DPW offers the unique opportunity to superimpose any kind of 3D data (surfaces of other glacial stages, geodetically measured data, etc.) on the stereomodel selected.

The photogrammetric mapping was restricted to an area of interest in the central part of Gössnitzkees (Figure 4). 
5.1.2 Intergraph (ISAE): In a further step we proceeded to automate the time-consuming collection of elevation data for computing a DEM. Model setup was done as outlined in the previous section. Since the software used is optimized for conventional aerial surveys, the automatic measurement of grid points failed completely. A simple 3D coordinate transformation (Gauss-Krüger coordinates into local coordinates, 6-parameter similarity transformation) helped us to simulate an appropriate "aerial imaging disposition". Following this coordinate transformation (new Z-axes parallel to the azimuth direction of the longitudinal profile), automatic DEM measurement still failed. After masking the foreground (= two areas, one to the left and one to the right of the proglacial lake, both representing ridges in object space, see Figure 4), ISAE (ImageStation Automatic Elevation) worked perfectly well for the area of interest. Finally, the resulting DEM and other features mapped had to be geometrically transformed back to the target (Gauss-Krüger) coordinate system.

\subsection{SfM-based approaches}

Structure-from-Motion (SfM) is an established image-based technique for automatically deriving sparse/dense point clouds of 3D objects/surfaces (Micheletti, 2015). Many commercial software solutions are currently on the market. In the present study we wanted to investigate whether and how the evaluation of the available photographs of Gössnitzkees can be automated. The main focus was on automation of image orientation and DEM computation. We studied different scenarios: a) multiimage ( $>2$ photographs) solution vs. stereomodel only (2 photographs), b) field calibration vs. IO from pre-calibration, and c) usage of original images vs. idealized/normalized images. The following three software packages were tested: PhotoModeler Scanner v. 2015 (PhotoModeler Scanner, 2016), Agisoft PhotoScan v. 1.1.6 (Agisoft PhotoScan, 2016), and Pix4Dmapper Pro v. 2015 (Pix4Dmapper Pro, 2016).

\subsection{Time-lapse computer animation}

Surface deformation/change can be nicely visualized using the available (time-lapse) photographs. Since all images were taken from the same positions, images from the same standpoint can be transformed geometrically into a common image geometry using a 2D homography (perspective transformation). Geometric and radiometric adjustment was done by means of in-house developed Matlab-based software. Key frames of selected epochs were merged to form animated GIFs.

\section{RESULTS}

\subsection{Intercomparison of methods}

6.1.1 DWP (ImageStation): All three glacial stages were reconstructed in high quality as expected from previous projects. Accuracy assessment of the derived DEMs was carried out by comparing the geodetically derived profiles with the respective profiles interpolated from the multi-temporal DEMs. Numerical values are given in Figure 5. Systematic vertical offsets/biases exist. The precision $\left(\mathrm{SD}_{\mathrm{Z}}\right)$ of a single photogrammetric height value along the vertical profile is in the range of \pm 0.11 to $\pm 0.16 \mathrm{~m}$. The results obtained are in good agreement with those of previous projects (cp. with Kaufmann \& Ladstädter, 2008b, and Kaufmann, 2010).

The comparison of the manually measured DEM with the automatically derived DEM showed good agreement (Bias in Z
$=0.02 \mathrm{~m}, \mathrm{SD}_{\mathrm{Z}}= \pm 0.09 \mathrm{~m}$ ). This specific investigation, however, was carried out for a data set of 2010, which is not included in this study.

6.1.2 SfM-based approaches: Various tests were carried out to identify the potential of each software package.

PhotoModeler Scanner: With our data set we were not able to complete the present glacier change study successfully in a fully automatic mode. PhotoModeler with SmartMatch did not provide sufficient homologous points, i.e., sparse tie points, for appropriate relative orientation of the image quadruple. Subsequently, dense surface modeling/dense image matching failed in the same areas where SmartMatch had failed. We believe that successful image matching for both tasks was hampered by the inherent large local parallax changes due to the slanted viewing direction. Other parameter settings might solve the encountered problems. Nonetheless, PhotoModeler offers a good choice of interactive mapping tools and sufficient flexibility in bundle adjustment serving specific photogrammetric needs.

Agisoft PhotoScan: In a first experiment we incorporated all four photographs (L, M1, M2, and R) in 3D mapping using appropriate camera calibration. Up to 31 GCPs were measured in each epoch. The accuracies of the three bundle adjustments are highly comparable (Table 1). The positional error amounts to $\pm 0.3 \mathrm{~m}$, and the vertical error $\pm 0.06-0.08 \mathrm{~m}$. The positional reprojection error is about \pm 0.4 pixels. Grid-based DEMs $(2.5 \mathrm{~m}$ $\times 2.5 \mathrm{~m}$ ) were derived from the dense point clouds computed. The accuracies of the DEMs were assessed by means of the contemporary geodetically measured longitudinal profiles. The comparison reveals distinct positive systematic offsets of the photogrammetric profiles in respect to the geodetic profiles in the range of 0.1 to $0.5 \mathrm{~m}$, and a precision of the photogrammetric height measurements of about $\pm 0.1 \mathrm{~m}$ (Table 2 ). The bias in $\mathrm{Z}$ is mainly due to the different measurement techniques applied: the image-based approach measures the visible surface, whereas the geodetic in-situ measurement seeks to determine points closer to the glacier surface.

In a second experiment we used a stereopair (M2-R) only. IO parameters were taken from a camera calibration of 2008. The processing was done using idealized images. The accuracy obtained was assessed as indicated previously. For results see Tables $3 \& 4$. The results of these two experiments are equivalent from a statistical point of view.

Pix4Dmapper Pro: In general, the results obtained - we restricted ourselves to epoch 2015 - are highly comparable to those of Agisoft PhotoScan. Tables $5 \& 6$ summarize the statistical parameters for the joint processing of all 4 images. We again did two runs, i.e., one with and one without camera calibration. Unfortunately, Pix4Dmapper Pro intentionally does not allow the processing of simple stereopairs, i.e., two images only. For example, the processing of older archive material, e.g., the 1988 survey, where only stereopairs are available, would not be possible.

The ease of use and the robustness of both software packages (Agisoft PhotoScan, Pix4Dmapper Pro) for solving glacier monitoring tasks is convincing and they also provide comparable results. 


\subsection{Glacier change}

In this paper we present glaciologically relevant results derived from our manual mapping using the Intergraph DPW. A single stereomodel (M2-R) was evaluated for each epoch.

6.2.1 Surface height change: Basic information on surface height change was derived by subtracting the available multiannual DEMs from each other. Figures 6 \& 7 depict the mean annual surface height change of the central part of Gössnitzkees for the time periods 1988-2009 and 2009-2015, respectively. Encountered systematic vertical offsets, as described above, were certainly canceled out to a great extent. Detailed graphical and numerical presentations refer to the longitudinal profile. Figures $3 \& 5$ illustrate the surface height change for the time period 1988-2015. The surface of Gössnitzkees has lowered gradually with time. The mean annual change in ice thickness amounts to $-1.52 \mathrm{~m} /$ year for this time period. The respective value for the most recent time period 2009-2015 is -1.19 $\mathrm{m} /$ year. The decline in ice melt can be attributed to the thickening of the debris layer, which reduces ablation by shielding the ice underneath the debris cover (cp. with Kaufmann et al., 2015).

The results obtained confirm glacier retreat of the more recent past. The obvious negative mass balance of Gössnitzkees is also reflected in the equilibrium line altitude (ELA) computed for the longitudinal profile (Figure 8), which amounts to $2705 \mathrm{~m}$ for the observation period 1997-2009. This means that the entire central part of the glacier has a negative mass balance at all heights and that only some small areas in the higher elevations might have a positive balance. The glacial stages of 2012 and 2015 could not be incorporated in the computation of the ELA because the glacier has already become discontinuous in the area of interest/along the longitudinal profile in the upper elevations (cp. Figure 5).

6.2.2 Glacier length change: Gössnitzkees has receded approx. $179 \mathrm{~m}$ during the last 27 years measured in the direction of the longitudinal profile (Table 8).

6.2.3 Time-lapse computer animation: Informative computer animations can be viewed at Kaufmann (2016b).

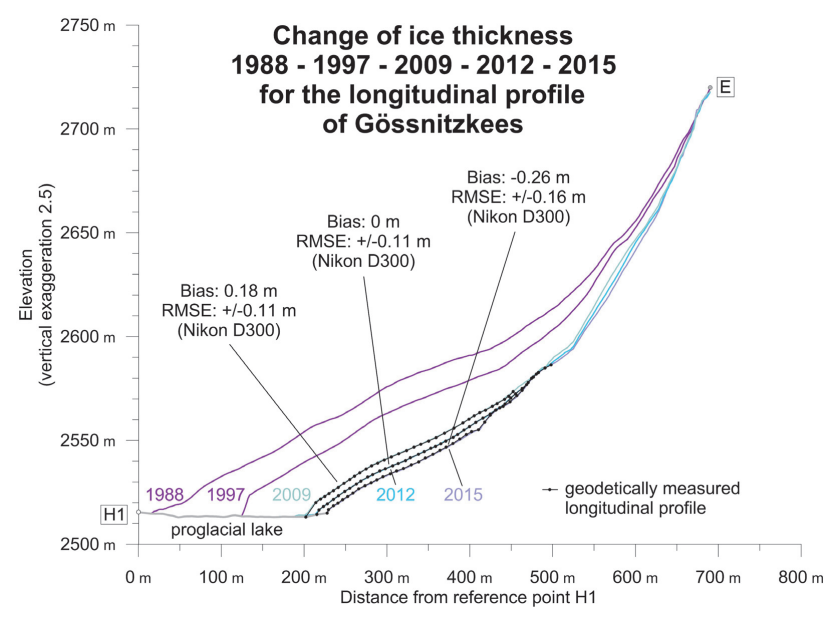

Figure 5. Change in ice thickness along the longitudinal profile of Gössnitzkees for the time period 1988-1997-2009-20122015.

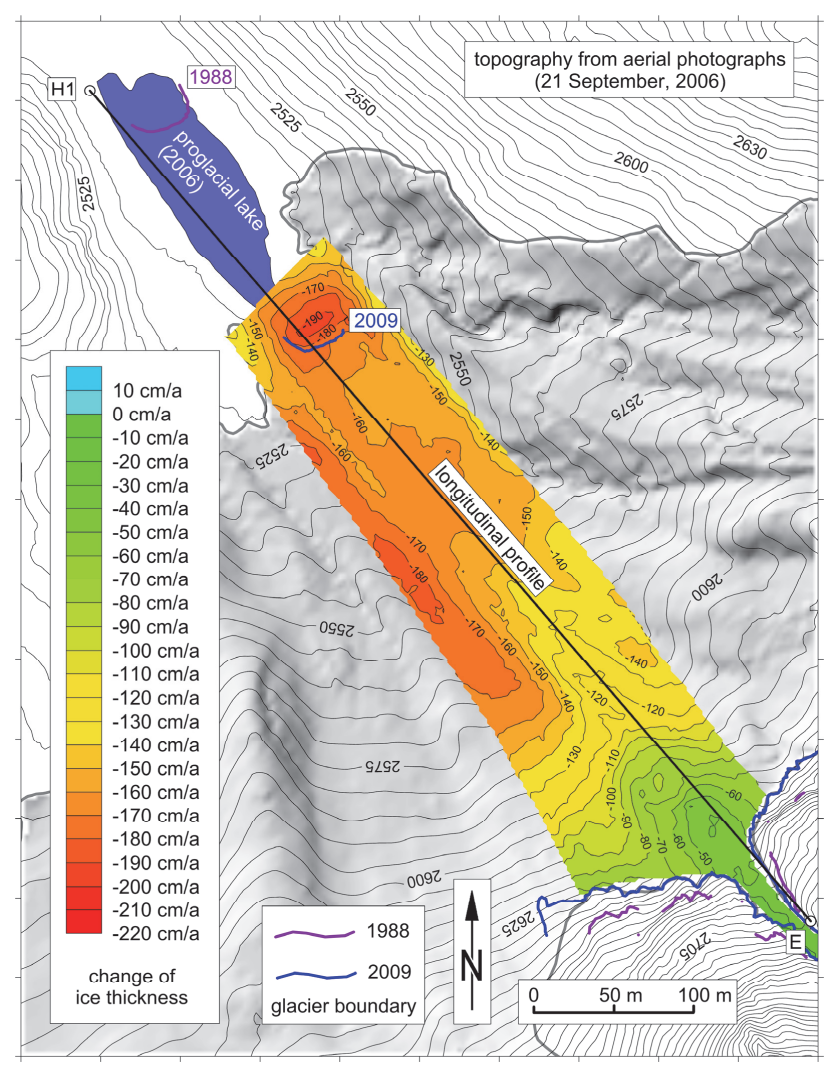

Figure 6. Terrestrial photogrammetric documentation of change in ice thickness of Gössnitzkees for the period 1988-2009.

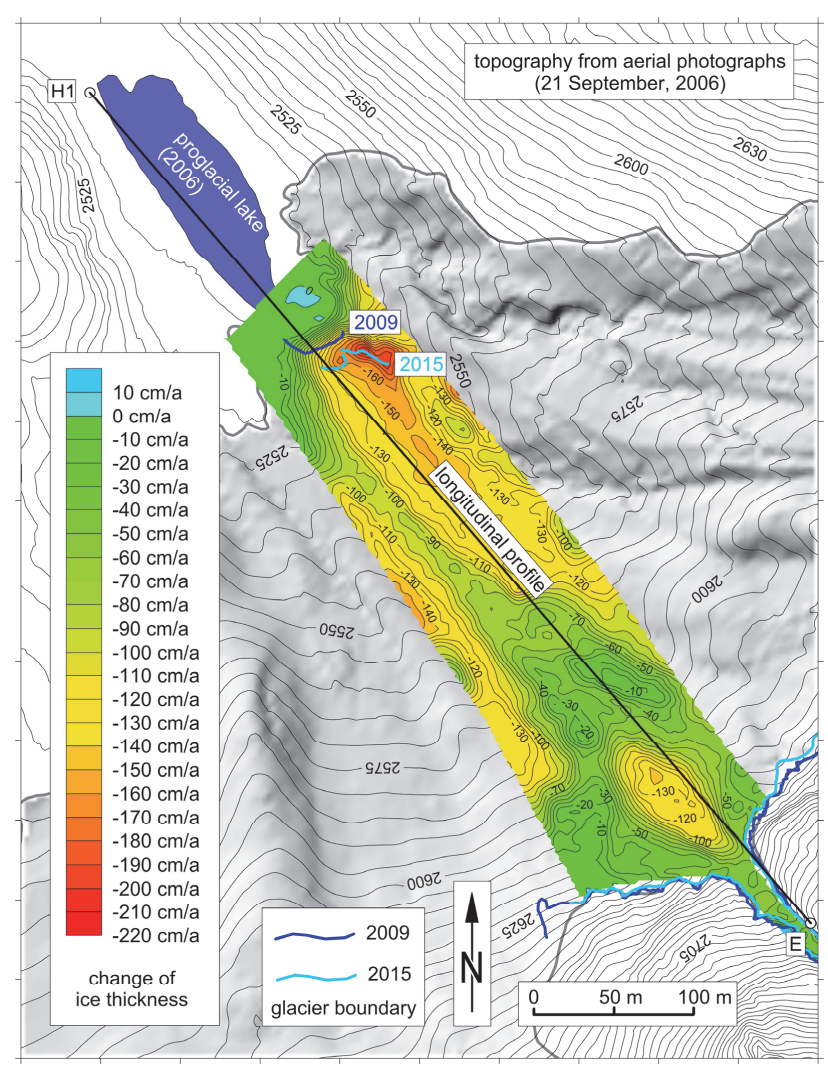

Figure 7. Terrestrial photogrammetric documentation of change in ice thickness of Gössnitzkees for the period 2009-2015. 


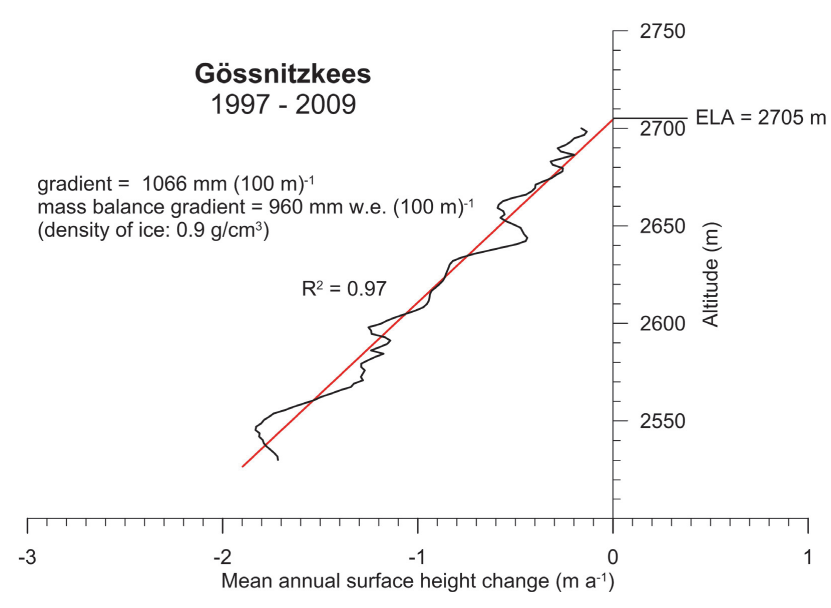

Figure 8. Estimation of equilibrium line altitude (ELA) for Gössnitzkees (longitudinal profile) for the period 1997-2009.

\begin{tabular}{|l|c|c|c|c|}
\hline Year & $\mathrm{N}$ & $\mathrm{RMS}_{\mathrm{XY}}(\mathrm{m})$ & $\mathrm{RMS}_{\mathrm{Z}}(\mathrm{m})$ & $\mathrm{RMS}_{\mathrm{xv}}(\mathrm{px})$ \\
\hline $2009^{\mathrm{a}}$ & 31 & \pm 0.34 & \pm 0.08 & \pm 0.40 \\
\hline $2012^{\mathrm{b}}$ & 27 & \pm 0.31 & \pm 0.07 & \pm 0.38 \\
\hline $2015^{\mathrm{b}}$ & 26 & \pm 0.30 & \pm 0.06 & \pm 0.44 \\
\hline
\end{tabular}

$\mathrm{N} \ldots$ number of ground control points

$\mathrm{RMS}_{\mathrm{XY}} \ldots$ horizontal root mean square positional error

$\mathrm{RMS}_{\mathrm{Z}} \ldots$ vertical root mean square error

$\mathrm{RMS}_{\mathrm{xy}} \ldots$ mean square positional error in image plane

a ... IO parameters adjusted: $\mathrm{c}, \mathrm{x}_{0}, \mathrm{y}_{0}, \mathrm{~K}_{1}-\mathrm{K}_{3}$

b... IO parameters adjusted: $c_{x}, c_{y}, x_{0}, y_{0}, K_{1}-K_{3}, B_{1}, B_{2}$

Table 1. Bundle adjustment with Agisoft PhotoScan (4 photographs, original image data).

\begin{tabular}{|c|c|c|}
\hline Year & Bias in $\mathrm{Z}(\mathrm{m})$ & $\mathrm{SD}_{\mathrm{Z}}(\mathrm{m})$ \\
\hline 2009 & +0.22 & \pm 0.07 \\
\hline 2012 & +0.13 & \pm 0.13 \\
\hline 2015 & +0.48 & \pm 0.09 \\
\hline
\end{tabular}

$+\ldots$ photogrammetric profile is systematically higher

$\mathrm{SD}_{\mathrm{Z}} \ldots$ standard deviation of photogrammetric $\mathrm{Z}$ value

Table 2. Accuracy of longitudinal profile. Photogrammetric data using Agisoft PhotoScan (4 photographs, original image data).

\begin{tabular}{|c|c|c|c|c|}
\hline Year & $\mathrm{N}$ & $\mathrm{RMS}_{\mathrm{XY}}(\mathrm{m})$ & $\mathrm{RMS}_{\mathrm{Z}}(\mathrm{m})$ & $\mathrm{RMS}_{\mathrm{xy}}(\mathrm{px})$ \\
\hline 2009 & 36 & \pm 0.33 & \pm 0.08 & \pm 0.20 \\
\hline 2012 & 22 & \pm 0.42 & \pm 0.09 & \pm 0.14 \\
\hline 2015 & 32 & \pm 0.36 & \pm 0.06 & \pm 0.23 \\
\hline
\end{tabular}

IO parameters taken from pre-calibration 2008

Table 3. Bundle adjustment with Agisoft PhotoScan (stereopair M2-R, idealized image data).

\begin{tabular}{|c|c|c|}
\hline Year & Bias in Z $(\mathrm{m})$ & $\mathrm{SD}_{\mathrm{Z}}(\mathrm{m})$ \\
\hline 2009 & +0.25 & \pm 0.11 \\
\hline 2012 & +0.09 & \pm 0.08 \\
\hline 2015 & +0.26 & \pm 0.09 \\
\hline
\end{tabular}

Table 4. Accuracy of longitudinal profile. Photogrammetric data using Agisoft PhotoScan (stereopair M2-R, idealized image data).

\begin{tabular}{|l|c|c|c|c|}
\hline Type & $\mathrm{N}$ & $\mathrm{RMS}_{\mathrm{XY}}(\mathrm{m})$ & $\mathrm{RMS}_{\mathrm{Z}}(\mathrm{m})$ & $\mathrm{RMS}_{\mathrm{xy}}(\mathrm{px})$ \\
\hline original $^{\mathrm{c}}$ & 29 & \pm 0.58 & \pm 0.12 & \pm 0.42 \\
\hline idealized $^{\mathrm{d}}$ & 29 & \pm 0.38 & \pm 0.06 & \pm 0.35 \\
\hline
\end{tabular}

c... IO parameters adjusted: $c_{\mathrm{x}}, \mathrm{c}_{\mathrm{y}}, \mathrm{x}_{0}, \mathrm{y}_{0}, \mathrm{~K}_{1}-\mathrm{K}_{3}$

d ... pre-calibration 2008

Table 5. Bundle adjustment with Pix4Dmapper (2015 image data, 4 photographs).

\begin{tabular}{|l|c|c|}
\hline Type & Bias in Z $(\mathrm{m})$ & $\mathrm{SD}_{\mathrm{Z}}(\mathrm{m})$ \\
\hline original $^{\mathrm{c}}$ & +0.28 & \pm 0.08 \\
\hline idealized $^{\mathrm{d}}$ & +0.31 & \pm 0.07 \\
\hline
\end{tabular}

Table 6. Accuracy of longitudinal profile. Photogrammetric data using Pix4Dmapper (4 photographs).

\begin{tabular}{|l|c|c|}
\hline Time period & $\begin{array}{c}\text { Surface height } \\
\text { change }^{*}(\mathrm{~m})\end{array}$ & $\begin{array}{c}\text { Mean annual change in } \\
\text { ice thickness }^{*}(\mathrm{~m} / \text { year })\end{array}$ \\
\hline $2009-2012$ & $-4.28[-4.20]$ & $-1.43[-1.40]$ \\
\hline $2012-2015$ & $-3.56[-3.28]$ & $-1.19[-1.09]$ \\
\hline $2009-2015$ & $-7.86[-7.41]$ & $-1.31[-1.24]$ \\
\hline $1988-2015$ & $-40.98[$ no data] & -1.52 [no data] \\
\hline
\end{tabular}

*... height interval 2530-2560 $\mathrm{SD}_{\Delta \mathrm{Z}}$ is estimated at $\pm 0.21 \mathrm{~m}$ [ ] ... geodetically derived value

Table 7. Change in surface height/ice thickness along the longitudinal profile.

\begin{tabular}{|l|l|}
\hline Time period & Glacier length change \\
\hline $2009-2012$ & $-24.8 \mathrm{~m}(=-8.26 \mathrm{~m} /$ year $)$ \\
\hline $2012-2015$ & $-14.3 \mathrm{~m}(=-4.78 \mathrm{~m} /$ year $)$ \\
\hline $2009-2015$ & $-39.1 \mathrm{~m}(=-6.52 \mathrm{~m} /$ year $)$ \\
\hline $1988-2015$ & $-179.4 \mathrm{~m}(=-6.64 \mathrm{~m} /$ year $)$ \\
\hline
\end{tabular}

Table 8. Glacier length change

\section{DISCUSSION AND OUTLOOK}

The results presented confirm that terrestrial photogrammetry is a suitable technique for $3 \mathrm{D}$ data capture of localized areas such as glacier tongues. DPWs are primarily designed for aerial surveys in normal-case geometry and thus do not support terrestrial projects appropriately. Automatic image matching/orientation and thus automatic DEM generation are therefore likely to fail in such cases. On the other hand, modern SfM-based software supports not only the fully automatic triangulation of any kind of terrestrial photographs but also the computation of high-resolution DEMs by means of dense image matching. The ease and robustness of the successful SfM software is convincing. The DEMs obtained have a high quality and generally outperform manually derived DEMs.

We recommend integrating modern computer vision technology into DPWs or including 3D viewing and measuring capabilities in current SfM-based solutions. In our study we found that the precise measurement of natural (non-signalized) ground control points is difficult to achieve monoscopically and often error prone. Thus, image resolution should be very high for good point identification. Automatic image-based registration of multi-temporal surveys using stable areas/surfaces (of a reference epoch) is also worth considering. 
Photogrammetric stereomodels and image blocks are prone to systematic deformations. Highly accurate measurements, appropriate camera models and sufficient GCPs (number, distribution) help keep these systematic errors to a minimum.

SfM techniques allow successful glacier mapping using two images only if the base-to-distance ratio of the stereo setup is appropriate, the image contrast/texture is good, and sufficient GCPs are available. A key pre-requisite is, of course, a reliable camera pre-calibration. Highest mapping accuracy, however, can only be obtained through an in-situ camera calibration, which requires multiple view geometry and good GCPs.

In general, the topographic situation of the area of interest will mainly define the potential of terrestrial photogrammetry for a specific mapping task.

The pros and cons of terrestrial photogrammetry in glacier mapping are as follows. Pros: (1) Data acquisition is easy and inexpensive. Consumer-grade digital cameras are comparatively cheap. A minimum of two persons (photographer \& fellow mountaineer) are required for data acquisition and mountain safety. The lightweight equipment comprises both the camera system and a tripod. (2) Data evaluation is highly automatic. In the optimal case the area of interest includes a sufficient number of stable areas for datum definition/geometric control.

Cons: (1) Cumbersome georeferencing using GCPs. GCPs for datum definition must be provided by other external measurements (RTK-GNSS, total station, etc.). Measurement of GCPs in the image space may prove difficult in some cases. (2) Vulnerability to systematic model/image block deformation due to erroneous IO or inappropriate ground control. (3) Present SfM-based software does not support large-scale $3 D$ viewing and advanced $3 D$ feature collection.

The authors believe that democratization of terrestrial photogrammetry as outlined in this paper can provide an impetus to volunteer glacier change mapping providing more quantitative information for mountain studies. A future scenario might be a real-time smartphone application for detection of surface change based on time series of, for example, photographs taken on an annual basis. Such an application could also be used in the monitoring of rock glaciers or rock slopes.

\section{ACKNOWLEDGEMENTS}

The authors gratefully acknowledge support from NAWI Graz. The hill-shade of Figure 1 is based on a DEM provided by TIRIS, Land Tirol. The financial support of Hohe Tauern National Park Carinthia and OeAV-Patenschaftsfonds Nationalpark Hohe Tauern is kindly acknowledged. The hosts of Elberfelderhütte (http://www.dav-barmen-wuppertal.de/) are thanked for their commitment.

\section{REFERENCES}

Abermann, J., Fischer, A., Lambrecht, A. \& Geist, T., 2010. On the potential of very high-resolution repeat DEMs in glacial and periglacial environments. The Cryosphere, 4(1), pp. 53-65. doi:10.5194/tc-4-53-2010

Agisoft PhotoScan, 2016. http://www.agisoft.com/ (12 March 2016)
Deline, P., Gruber, S., Delaloye, R., Fischer, L., Geertsema, M., Giardino, M., Hasler, A., Kirkbride, M., Krautblatter, M., Magnin, F., McColl, S., Ravanel, L. \& Schoeneich, P., 2015. Ice loss and slope stability in high-mountain regions. In: Snow and Ice-Related Hazards, Risks, and Disasters, Chapter 15, Elsevier, pp. 521-561.

Fischer, A., 2011. Comparison of direct and geodetic mass balances on a multi-annual time scale. The Cryosphere, 5(1), pp. 107-124. doi:10.5194/tc-5-107-2011

Fischer, A., 2015. Gletscherbericht 2013/2014. In: Bergauf, 2015(2), in German, pp. 26-33.

Fischer, A., Stocker-Waldhuber, M., Seiser, B., Hynek, B. \& Slupetzky, H., 2014. Glaciological monitoring in Hohe Tauern National Park. eco.mont, 6(1), pp. 55-62.

Fischer, A., Seiser, B., Stocker-Waldhuber, M., Mitterer, C. \& Abermann, J., 2015a. Tracing glacier changes in Austria from the Little Ice Age to the present using a lidar-based highresolution glacier inventory in Austria. The Cryosphere, 9(2), pp. 753-766. doi:10.5194/tc-9-753-2015

Fischer, A. et al., 2015b. The Austrian Glacier Inventories GI 1 (1969), GI 2 (1998), GI 3 (2006), and GI LIA in ArcGIS (shapefile) format. doi:10.1594/PANGAEA.844988, supplement to Fischer et al. (2015a)

Huss, M., 2013. Density assumption for converting geodetic glacier volume change to mass change. The Cryosphere, 7(3), pp. 877-877. doi: 10.5194/tc-7-877-2013

ImageStation, 2016. http://www.hexagongeospatial.com/en/ products/producer-suite/imagestation (12 March 2016)

Kajuutti, K., Pitkänen, T., Haggrén, H. \& Pellikka, P., 2010. Terrestrial photogrammetry in glacier studies. In: Pellikka, P. \& Rees, W.G., Remote Sensing of Glaciers: Techniques for Topographic, Spatial and Thematic Mapping of Glaciers. CRC Press/Balkema, Chapter 6, pp. 99-113.

Kaufmann, V., 2010. Dokumentation des Gletscherrückgangs am Gössnitzkees (Schobergruppe, Hohe Tauern) für den Zeitraum 1988-2009 mittels terrestrischer Photogrammetrie. In: DGPF Tagungsband 19/2010 - Dreiländertagung OVG, DGPF und SGPF, Vienna, Austria, in German, pp. 513-522.

Kaufmann, V., 2012. The evolution of rock glacier monitoring using terrestrial photogrammetry: the example of Äußeres Hochebenkar rock glacier (Austria). Austrian Journal of Earth Sciences, 105(2), pp. 63-77.

Kaufmann, V., 2016a. http://www.geoimaging.tugraz.at/ viktor.kaufmann/Goessnitzkees.html (12 March 2016)

Kaufmann, V., 2016b. http://www.geoimaging.tugraz.at/ viktor.kaufmann/animations.html (12 March 2016)

Kaufmann, V. \& Plösch, R., 2000. Mapping and visualization of the retreat of two cirque glaciers in the Austrian Hohe Tauern National Park. In: International Archives of Photogrammetry and Remote Sensing, Amsterdam, Holland, Vol. XXXIII, Part B4, pp. 446-453.

Kaufmann, V. \& Lieb, G.K., 2002. Investigation on the Retreat of two small cirque glaciers (Gössnitzkees and Hornkees) in the Austrian Alps, Europe. In: High-Mountain Remote Sensing 
Cartography 1998 - Proceedings of the 5th International Symposium on the Use of Remote Sensing Data in Mountain Cartography, Karlstad University Studies 2002:27, pp. 75-82.

Kaufmann, V. \& Ladstädter, R., 2004. Documentation of the retreat of a small debris-covered cirque glacier (Gössnitzkees, Austrian Alps) by means of terrestrial photogrammetry. In: Proceedings of the 4th ICA Mountain Cartography Workshop, Vall de Núria, Catalonia, Spain, Monografies tècniques 8, Institut Cartogràfic de Catalunya, Barcelona, pp. 65-76.

Kaufmann, V. \& Ladstädter, R., 2008a. Documentation of the Retreat of Gössnitzkees and Hornkees Glaciers (Hohe Tauern Range, Austria) for the Time Period 1997-2006 by Means of Aerial Photogrammetry. In: Proceedings of the 6th ICA Mountain Cartography Workshop, Lenk, Switzerland, pp. 115123.

Kaufmann, V. \& Ladstädter, R., 2008b. Application of terrestrial photogrammetry for glacier monitoring in alpine environments. In: The International Archives of the Photogrammetry, Remote Sensing and Spatial Information Sciences, Beijing, China, Vol. XXXVII, Part B8, pp. 813-818.

Kaufmann, V., Dorn, M., Patri, G.-P., Reimond, S. \& Sulzer, W., 2013. Digital Camera Nikon D300 in Support of High Mountain Studies in the Langtang Valley, Central Himalaya, Nepal. Universal Journal of Geoscience, 1(1), pp. 1-9. doi: 10.13189/ujg.2013.010101

Kaufmann, V., Kellerer-Pirklbauer, A., Lieb, G.K., Slupetzky, H. \& Avian, M., 2015. Glaciological Studies at Pasterze Glacier (Austria) Based on Aerial Photographs. In: Li, J. \& Yang, X. (eds.): Monitoring and Modeling of Global Changes: A Geomatics Perspective. Springer Remote Sensing/Photogrammetry, Springer Science+Business Media Dordrecht, pp. 173-198. doi: 10.1007/978-94-017-9813-6 9

Kääb, A., 2005. Remote Sensing of Mountain Glaciers and Permafrost Creep. Schriftenreihe Physische Geographie, 48, Geographisches Institut, Universität Zürich, 264 p.

Kellerer-Pirklbauer, A., Bauer, A. \& Proske, H., 2005. Terrestrial laser scanning for glacier monitoring: Glaciation changes of the Gößnitzkess glacier (Schober group, Austria) between 2000 and 2004. In: Conference Volume. 3rd Symposium of the Hohe Tauern National Park for Research in Protected Areas, Kaprun, Austria, pp. 97-106.

Kriz, K., 2015. Alpine Club Mapping - 150 Years of Cartography. In: Mountain Cartography - 16 Years ICA Commission on Mountain Cartography (1999-2015), Wiener Schriften zur Geographie und Kartographie, Vol. 21, Department of Geography and Regional Research, University Vienna, Austria, pp. 153-160.

Lambrecht, A. \& Kuhn, M., 2007. Glacier changes in the Austrian Alps during the last three decades, derived from the new Austrian glacier inventory. Annals of Glaciology, 46(1), pp. 177-184.

Lieb, G.K., 2000. Die Flächenänderungen von Gössnitz- und Hornkees (Schobergruppe, Hohe Tauern) von 1850 bis 1997. In: 1960-2000 - 40 Jahre Glaziologische Forschung (Festschrift für Heinz Slupetzky zum 60. Geburtstag), Salzburger Geographische Arbeiten, Band 36, Institut für Geographie und angewandte Geoinformatik, Universität Salzburg, in German, pp. 83-96.

Maas, H.-G., Casassa, G., Schneider, D., Schwalbe, E. \& Wendt, A., 2012. Photogrammetric Techniques for the Determination of Spatio-temporal Velocity Fields at Glaciar San Rafael, Chile. Photogrammetric Engineering \& Remote Sensing, 79(3), pp. 299-306.

Mayer, C., 2010. The early history of remote sensing of glaciers. In: Pellikka, P. \& Rees, W.G., Remote Sensing of Glaciers: Techniques for Topographic, Spatial and Thematic Mapping of Glaciers. CRC Press/Balkema, pp. 67-80.

Micheletti, N., Chandler, J.H. \& Lane, S.N., 2015. Section 2.2: Structure from Motion (SfM) Photogrammetry. In: Cook, S.J., Clarke, L.E. \& Nield, J.M. (Eds.) Geomorphological Techniques (Online Edition). British Society for Geomorphology; London, UK. ISSN: 2047-0371.

Patzelt, G., 1980. The Austrian glacier inventory: status and first results. In: Proceedings of the Riederalp Workshop, September 1978, IAHS-AISH Publ. no. 126, pp. 181-183.

Paul, F. et al., 2015. The glaciers climate change initiative: Methods for creating glacier area, elevation change and velocity products. Remote Sensing of Environment, 162, pp. 408-426.

PhotoModeler Scanner, 2016. http://www.photomodeler.com/ products/scanner/ (12 March 2016)

Pix4Dmapper Pro, 2016. https://www.pix4d.com/ (12 March 2016)

Rinner, K. \& Burkhardt, 1972. Gletscherphotogrammetrie. In: Handbuch der Vermessungskunde (Jordan/Eggert/Kneissl), Band III a/2 Photogrammetrie, J.B. Metzlersche Verlagsbuchhandlung, Stuttgart, in German, § 121, pp. 14281470 .

Rüdenauer, H., 1996. The low cost remote sensing system "LARSS" for environmental monitoring and photogrammetric applications. In: International Archives of Photogrammetry and Remote Sensing, Vienna, Austria, Vol. XXXI, Part B1, pp. 167169.

Sanz-Ablanedo, E., Chandler, J.H. \& Irvine-Fynn, T.D.L., 2012. Studying glacial melt processes using sub-centimeter DEM extraction and digital close-range photogrammetry. In: The International Archives of the Photogrammetry, Remote Sensing and Spatial Information Sciences, Melbourne, Australia, Vol. XXXIX, Part B5, pp. 435-440.

Wakonigg, H., 2007. Klima im Wandel. LIT Verlag, Vienna, in German, 188 p.

Winkler, S., Chinn, T., Gärtner-Roer, I., Nussbaumer, S.U., Zemp, M. \& Zumbühl, H.J., 2010. An introduction to mountain glaciers as climate indicators with spatial and temporal diversity. Erdkunde, 64(2), pp. 97-118.

Zemp, M., Thibert, E., Huss, M., Stumm, D., Rolstad Denby, C., Nuth, C., Nussbaumer, S.U., Moholdt, G., Mercer, A., Mayer, C., Joerg, C.P., Jansson, P., Hynek, B., Fischer, A., Escher-Vetter, H., Elvehøy, H. \& Andreassen, L.M., 2013. Reanalysing glacier mass balance measurement series. The Cryosphere, 7(4), pp. 1227-1245. doi:10.5194/tc-7-1227-2013 